\title{
Forging Enmities and Friendships: Europarties, Electoral Coalitions and Mergers in Central and Eastern Europe
}

\begin{abstract}
The inability of Europarties to provide the electoral linkage between its citizens and policymakers is a key challenge to the European Union. However, relatively young and unstable parties and party systems in Central and Eastern Europe present greater opportunities for the Europarties to impact electoral politics in this region. This research examines the influence of the most established Europarties on electoral coalitions and mergers among CEE parties. A cross-national comparative analysis of $11 \mathrm{CEE}$ countries in the first two decades after their democratic transitions suggests a moderately strong effect of the Europarties. Europarties facilitate mergers of their member or potential member parties and prevent electoral coalitions between their member and potential member parties and radical left and right parties.
\end{abstract}

Wordcount: 8890. 


\section{Introduction}

The development of Europarties is crucial for a viable democracy in the European Union. Although the EU meets the formal criteria of a procedural democracy, the representation of citizens' preferences in the policies adopted by the EU and the electoral accountability of EU institutions are unlikely in the absence of cohesive Europarties. The consensus among academics and policy practitioners is that even the most developed Europarties (the European People's Party (EPP) and the Party of European Socialists (PES)) are still far from assuring an effective electoral linkage between the EU institutions and its citizens. Indeed, although European party groups are increasingly cohesive in the European Parliament, national political parties rather than Europarties remain key players in European and especially national elections.

This established view of the under-institutionalisation of Europarties is however partially challenged by their role in the party politics of Central and Eastern Europe (CEE). As parties in this region were established after the fall of communism (with the notable exception of communist successor parties), and remained relatively fluid ever since (Ibenskas and Sikk, 2017), the Europarties might have been able to influence substantially their policies and internal organisation as well as the patterns of party cooperation and competition. A number of studies documented the activity of several Europarties, such as the EPP, the PES, or the European Liberal and Democratic Reform Party $(\mathrm{ELDR})^{1}$, in the post-communist setting since early 1990s. Several authors find strong effects of the Europarties (Pridham, 2006; Delsoldato, 2002; Spirova, 2008), thus suggesting that their role in the CEE context is substantially more important than usually acknowledged. At the same time, other researchers qualify the arguments about the importance of the Europarties (Haughton, 2009; Holmes and Lightfoot, 2011) or emphasise the lack of systematic empirical research on the topic (von dem Berge and Poguntke, 2013, 329).

We contribute to this debate on the relevance of Europarties in post-communist democ-

\footnotetext{
${ }^{1}$ This party was renamed as the Alliance of Liberals and Democrats for Europe (ALDE) in 2012.
} 
racies by providing the first comparative quantitative analysis of their impact on electoral coalitions in national parliamentary elections and party mergers in $11 \mathrm{CEE}$ countries since the beginning of their democratic transition. ${ }^{2}$ Specifically, we focus on the extent to which the Europarty is able to convince its member or potential member parties in CEE to coalesce among themselves and, conversely, to prevent the cooperation of these parties with other national parties that are ideologically distinct from the Europarty. The analysis thus sheds light on whether the key Europarties have been able to actively shape their organisational and ideological institutionalisation (Bressanelli, 2014) when integrating parties from postcommunist democracies and, more generally, the potential of Europarties to develop into genuine EU-wide parties.

Theoretically, we draw on the literature on Europeanisation, which suggests two mechanisms of Europarty influence: socialisation and the provision of benefits in exchange for the cooperation between its (potential) member parties. Recognising that multiple other factors affect parties' predispositions to cooperate (as well as their decisions to join Europarties), we control for these explanations by drawing on comparative research on electoral coalitions and mergers. Our empirical analysis shows moderate influence of Europarties: they facilitate the mergers (but not electoral coalitions) of their member or potential member parties, and prevent electoral coalitions between (1) their (potential) member parties and (2) radical left or right parties.

In addition to showing the relevance of Europarties as electoral organisations, our findings are important for two other reasons. First, studying the impact of international actors on party electoral coalitions and mergers as part of their broader aid to parties in young democracies is highly relevant given the substantial amount of financial and other resources spent on these activities (Carothers, 2006). Second, electoral coalitions and mergers can have important consequences on the performance and even survival of these democracies. Parties in many young democracies are less stable than those in Western democracies. This

\footnotetext{
${ }^{2}$ Electoral coalitions are defined as joint candidate lists. Party merger refers to the integration of two or more party organisations into a single party.
} 
study records that, in 64 parliamentary elections that took place in 11 Central and Eastern European democracies in the period between 1990 and 2012, the average number of electoral coalitions (each including two or more individual parties) was 1.8. Furthermore, on average 1.1 merged parties were formed in 53 electoral periods covered in this study. Consequently, electoral coordination through these forms of party cooperation has important consequences on electoral outcomes, government formation and, ultimately, policy outcomes. Electoral coalitions and mergers can also have negative consequences on democracy when, in the context of weak programmatic structuration of party systems, they are formed between ideologically dissimilar partners for purely opportunistic motives of obtaining office. The resulting flux in party alternatives may prevent voters from forming attachments to parties, learning about their policy positions and holding parties accountable. Coalitions and mergers may also be crucial for the substance of party systems in new democracies in the long term, as they allow parties to politicise certain cleavages and de-politicise others (Zielinski, 2002). Indeed, "a crucial point in the discussion of the translation of the cleavage structures into party systems [concerns] the costs and the pay-offs of mergers, alliances, and coalitions" (Lipset and Rokkan 1967, 112).

\section{Europarties and electoral coalitions and mergers in Cen- tral and Eastern Europe}

\section{Understanding electoral coalitions and party mergers: the state-of- the-art}

The comparative research on the formation of electoral coalitions and party mergers explains these phenomena from a rational choice institutionalist perspective. Specifically, party coordination depends on its costs and benefits in terms of votes and seats, office and policy. Both electoral coalitions and mergers may increase parties' legislative representation 
by helping them to overcome legislative thresholds (Blais and Indridason, 2007; Ferrara and Herron, 2005; Golder, 2005; Ibenskas, 2016a; Kaminski, 2001). By coalescing and merging, parties can also increase their chances to enter government. For example, they may form the largest legislative bloc (Golder, 2006; Spirova, 2007), or become pivotal in a larger number of alternative coalitions compared to the absence of party coordination (Ibenskas, 2016a). Parties may also form electoral coalitions in order to prevent the emergence of governments with very different ideological positions than their own (Golder, 2006).

However, both coalitions and mergers also imply various costs. Ideological differences increase the cost of policy compromises and could lead to substantial electoral losses (Golder, 2006; Gschwend and Hooghe, 2008). Coalitions between genuinely new parties and established parties are also less compatible electorally, as they undermine the valence appeal of new parties (Ibenskas, 2016b). Another cost of electoral coalitions is related to the distribution of electoral candidacies and office benefits. Specifically, the open or flexible-list PR system reduces the credibility of inter-party deals on the sharing of positions on the joint candidate lists, while the lack of previous cooperation, similar to the case of government coalitions, increases the bargaining costs of reaching coalition deals (Ibenskas, 2016b).

These studies stressed the importance of costs and benefits of electoral coalitions and mergers for parties that are determined by the characteristics of these parties themselves and the national context of party competition. However, electoral coalitions and mergers are also important "dependent variables" in the studies on the impact of the Europarties and other actors in the transnational party family networks (e.g. party groups of the European Parliament, party internationals, national parties and their foundations) on political parties and party systems in post-communist states. ${ }^{3}$ There is some case study evidence that the Europarties tried and, at least in some cases, succeeded in promoting electoral coalitions and mergers between national parties that belonged to their respective party families (Öhlén,

\footnotetext{
${ }^{3}$ Key party internationals are the Centrist Democratic International (CDI; Christian Democratic International until 2000), the International Democrat Union (IDU), the Liberal International (LI), and the Socialist International (SI).
} 
2013; Pridham, 2006; Spirova, 2008; Timuş, 2014; von dem Berge and Poguntke, 2013). However, systematic empirical tests of the presence and extent of Europarty influence are missing in the literature.

\section{Electoral coalitions and mergers: Europarties' goals}

The Europarties are interested in electoral coalitions and mergers of parties in Central and Eastern Europe because they have direct effects on the Europarties' institutionalisation and influence. Furthermore, the Europarties, as key players in the EU political system, are also interested in assuring the development and entrenchment of democracy in CEE countries.

Europarty institutionalisation is defined here in terms of two dimensions: structural (organisational systemness and coherence) and attitudinal or value (the extent to which members of the party share its ideology and values) (Bressanelli, 2014; Randall and Svasand, 2002). Influence refers to the representation of the Europarty in the institutions of the EU.

We expect that the Europarties seek to promote certain coalitions and mergers and prevent others depending on how they affect Europarties' ability to achieve their goals. Table 1 summarises this logic in detail. Specifically, they should prefer the cooperation among their (full, associate, affiliate and observer) member parties and/or potential member parties (defined as parties that are considered by the Europarty as sufficiently ideologically close and that are not ruled out because of their affiliation with other Europarties or international party federations). Such coalitions and mergers may increase the legislative representation of these parties at both national and European levels, which would in turn strengthen the influence of the Europarty. They may also could contribute to democratic consolidation in a CEE country by reducing excessive party fragmentation. Moreover, such mergers streamline the organisation of Europarties by, for example, helping them to avoid situations where their national member parties compete against each other in electoral and parliamentary arenas at national and European levels. It is also important to note that Europarties are forward- 
looking actors that do not only try to increase their institutionalisation and influence by promoting coalitions and mergers among their current members, but also try to anticipate the consequences of potential member parties joining them in the future. As such, Europarties aim to influence potential member parties' coalition and merger behaviour.

\section{[Table 1]}

Second, the Europarties should be interested in preventing the cooperation between their (potential) member parties and radical left or right parties. In the first place, cooperation among moderate and extreme parties may present a threat to democracy in the country concerned. Moreover, if the national member party remains in the Europarty despite its cooperation with a radical party (or the merged party that includes an extremist component joins it after a merger), the identity of the Europarty as a representative of liberal democratic values is severely challenged. The Europarty would also be open to the criticism of competing Europarties and their national members, leading to the potential loss of electoral support and influence. Alternatively, the Europarty could choose to expel or terminate informal cooperation with the opportunist national party, but this implies a cost to the Europarty in terms of lower influence.

Europarties can be expected to be ambivalent about electoral coalitions and mergers between their (potential) member parties and the parties that represent different ideologies than the one of the Europarty. In some cases they may prefer the cooperation among moderate parties of different ideological shades if they see it as a way to preserve and strengthen liberal democracy. However, such coalitions and mergers threaten either the influence of the Europarty (if its member party or the merged party leaves following the formation of a merged party or electoral coalition) or its value institutionalisation (if, as a result of merger or electoral coalition, the Europarty includes a party or faction that does not share its core ideological principles). 


\section{Mechanisms of Europarties' influence: external incentives model}

The rationalist external incentives and constructivist socialisation models of Europeanisation (Schimmelfennig and Sedelmeier, 2005; Sedelmier, 2011; Vachudova, 2005; von dem Berge and Poguntke, 2013) suggest the mechanisms through the Europarties might be able to influence electoral coalitions and mergers in Central and Eastern Europe. The external incentives model, building on the "logic of consequences" (Hall and Taylor, 1996), posits that the Europarty provides various resources to CEE parties in exchange for them following the recommendations of the Europarty on on cooperating with some parties but not others. Specifically, Europarties may contribute to the electoral success of their member or potential member parties by providing material resources, training their elites and activists, or organising high-level meetings (featuring some of the most prominent European leaders) shortly before national or European elections to increase a party's reputation and visibility. Additionally, being a member of a Europarty that represents one of the mainstream ideologies sends an important signal about the party's ideological identity, and as such can provide an electoral advantage, especially given the high party instability and volatility in the region (Dakowska, 2002, 285; Delsoldato, 2002, 725; Spirova, 2008, 796). Furthermore, the Europarty can enhance the policy influence of the national party by providing it with institutionalised and regular access to key players in the European decision-making (e.g. governments of key EU member states). These and other resources may be sufficient to compensate for the costs of party change (Harmel and Janda, 1994) that the elites of the party experience when following the Europarty's recommendations on its coalition or merger strategy.

The credibility of the Europarty conditionality - determined by the "promise to deliver the reward in case of compliance" and the "threat to withhold the rewards in case of noncompliance" (Schimmelfennig and Scholtz, 2008, 191) - also affects its influence (Sedelmier, 2011, 12-15). for the promise to deliver benefits in the case of compliance to be credible, the Europarty needs to have linkages and contacts with the national party (cf. Kubicek, 
2003; Levitsky and Way, 2006; Sedelmier, 2011). While the Europarties are likely to sustain regular communication with their member parties, they may lack such links to some of their potential member parties. ${ }^{4}$ In the absence of regular communication between the Europarty and the national party, the latter may be uncertain about whether electoral coalitions and mergers in which it intends to participate would be rewarded by the Europarty. In contrast, if at least one of the parties in an electoral coalition or merged party has a communication link with the Europarty, the certainty about whether benefits would be provided is higher, and such benefits are likely to be awarded earlier.

The threat to withhold the rewards in case of non-compliance is more credible for potential member parties with whom the Europarty has only informal contacts. Withdrawing resources from the national party if it does not follow the recommendations from the Europarty on coalitions and mergers is less costly for the Europarty. The credibility of such threats is somewhat more limited in the case of the national parties that are already members of the Europarty, because they might not be excluded from certain benefits (e.g. attending Europarty meetings) without a formal exclusion or suspension (which is likely to be costly for the Europarty). However, the Europarty (and its core national parties in Western Europe) is still likely to be able to hold back some benefits, such as support in election campaigns, even from its full member parties. Thus, we argue that the threat to withdraw benefits in the case of non-compliance tends to quite credible for all cases analysed below.

\section{Mechanisms of Europarties' influence: socialisation model}

The socialisation model of Europeanisation builds on the "logic of appropriateness". Thus, the Europarties do not seek to change the calculus of the parties in CEE countries with regard to electoral coalitions and mergers. Instead, "as actors who represent a certain collective identity and a set of common norms and values at the European level" (von dem Berge

\footnotetext{
${ }^{4}$ Conversely, the Europarties may also establish regular communication with the parties that they do not consider ideologically acceptable, at least not in the short term, as demonstrated by the links between the Europarties and international socialist party organisations and partially reformed communist successor parties in the early 1990s.
} 
and Poguntke, 2013, 322), the Europarties aim to change the values and norms (including those related to party cooperation) of parties in post-communist countries through the processes of socialisation and persuasion. Parties in CEE countries are subject to both "indirect socialisation" and "direct socialisation" (von dem Berge and Poguntke, 2013). The former includes everyday interaction between CEE parties and their Western European counterparts that is not specifically aimed at influencing the electoral coalition and merger strategy. The former refers to activities (e.g. seminars or meetings) organised by representatives of Europarties or other member parties to persuade parties in CEE countries to form (or not to form) certain coalitions and mergers. Through both types of socialisation, CEE parties could form preferences on coalitions and mergers that are in line with those of Western European parties (e.g. opposition to electoral collaboration with radical right parties).

The intensity of contacts through transnational networks is one of the most important factors that affects the effectiveness of the socialisation and persuasion strategies of international actors (Checkel, 2005, 810-813; Schimmelfennig and Sedelmeier, 2005, 18-20; Sedelmier, 2011, 15-16). Parties in CEE that are members of the Europarty are likely to have more intense communication with the Europarties. However, the latter made a strong effort to socialise also their potential members in CEE. For example, Öhlén (2013) meticulously records numerous various trainings and seminars that key Europarties used to socialise their potential member parties in CEE countries in the 1990s. This points to the importance of the linkage between the Europarty and the parties in CEE as the key condition of the Europarty's socialising influence.

\section{Hypotheses}

The arguments above suggested that the Europarties seek to (1) encourage the cooperation between its (potential) member parties and (2) prevent the cooperation between the (potential) member parties on the one hand and radical left and right parties on the other 
hand. ${ }^{5}$ Both the external incentives and socialisation models, while suggesting very different mechanisms of the Europarty influence, indicate that the linkage in terms of intense contacts and communication between the Europarty and CEE parties is essential for this influence to be present. Such link is present for all member parties of Europarties as well as for some potential member parties with whom the Europarty has contacts. These arguments lead to the following hypotheses: ${ }^{6}$

H1: Member and potential member parties are more likely to form electoral coalitions when at least one of these parties shares a link with a Europarty.

H2: Member and potential member parties that have a link with a Europarty are less likely to form electoral coalitions with radical right or left parties.

H3: Member and potential member parties are more likely to merge when at least one of these parties shares a link with a Europarty.

H4: Member and potential member parties that have a link with a Europarty are less likely to merge with radical right or left parties.

\section{Data and measurement}

The theoretical expectations are tested using the data on electoral coalitions in parliamentary elections and party mergers in eleven Central and Eastern European countries that are currently member states of the EU. The dataset covers the period between the second democratic election in these countries following their transitions from the communist political system and the year 2012. ${ }^{7}$ The dataset includes all parties that obtained at least 1

\footnotetext{
${ }^{5}$ In contrast, the Europarty's attitude towards the cooperation between its (potential) member parties and other moderate parties is more ambivalent. Thus, no hypotheses are formulated for the influence of the Europarty on such coalitions and mergers.

${ }^{6}$ The proposed hypotheses do not isolate the causal mechanisms of the two theoretical models summarised above, but seek to establish a causal effect of Europarties. While causal effect is the key condition for demonstrating causal inferences (Gerring, 2011), future research could test the proposed mechanisms through case studies based on, for example, interviews with key informants and in-depth analysis of documentary evidence.

${ }^{7}$ This threshold was chosen for data availability reasons; the theoretical expectations of the study apply for the period after 2012 .
} 
percent of the vote in the election for which the coalition could be formed or in the last parliamentary election before a merged party could be formed. ${ }^{8}$ The analysis of electoral coalitions covers only joint candidate lists but not public commitments to govern together.

Following previous comparative research on electoral coalitions and mergers (Golder, 2006; Ibenskas, 2016b,a), the dataset is organised in a dyadic way. The unit of analysis is party dyad in an election (for the analysis of coalitions) or party dyad in an electoral period (for the analysis of mergers). Both dependent variables are dichotomous and take the value of 1 if the two parties in the dyad formed a coalition or merged, and 0 otherwise. The dataset in total includes 117 electoral coalitions in 64 elections and 59 merged parties in 53 electoral periods. Figure 1 presents the number of electoral coalitions and mergers per country.

[Figure 1]

The analysis considers the Europarties that unite socialist/social democratic parties (the PES), Christian democratic/ conservative parties (the EPP), and liberal parties (the ELDR). These three Europarties (especially the EPP and PES) were more institutionalised than all other European level party federations throughout the period analysed in the present research, and were active in all eleven countries analysed here (Pridham, 2006; Öhlén, 2013). The multitude of social democratic and especially Christian democratic, conservative and liberal parties in post-communist democracies (see, for example, Bakke (2010)) also justifies the research focus on party cooperation within these party families as opposed to other families (e.g. the Greens) that were significantly less prominent in these countries. ${ }^{9}$

[Table 2]

\footnotetext{
${ }^{8}$ This data was collected for the comparative analyses of electoral coalitions and mergers by Ibenskas $(2016 b)$ and Ibenskas (2016a). In the case where two or more parties participated in a pre-electoral coalition, their individual vote shares were estimated as the product of the coalition's vote share and the share of seats of the party from the total share of seats of the coalition.

${ }^{9}$ Given the focus on these three Europarties that are neither interested nor able to influence the coalition and merger decisions of radical right and communist parties, the analyses exclude the dyads in which both national parties are radical right and/or communist parties. Such dyads formed less than $2 \%$ of the whole sample.
} 
As a first step in constructing the variables for testing theoretical expectations, all partyelection and party-electoral period dyads are divided into five groups with respect to their relationship with each of the three Europarties. The first four categories characterise member and potential member of the Europarties (see Table 2 for the description of these codes and Figure 2 for the frequency of party-election dyads in the first four of these groups). They include: (1) full member parties, (2) associate, affiliate, or observer parties, (3) potential member parties with links to the Europarty, and (4) potential member parties with no links to the Europarty. ${ }^{10}$ The fifth group includes parties that were not member or potential member parties of the Europarty.

Potential member parties with ties to the Europarties are identified in two ways. First, observer, associate or full members of European party organisation other than the Europarty itself or international party confederations that belong to the same party family network as the Europarty were coded as its potential members. For the EPP, other organisations in its network include the European Union of Christian Democrats (EUCD), the European Democrat Union (EDU), and the Christian Democratic International (CDI); for the PES, the Socialist International (SI); and for the ELDR, the Liberal International (LI). All of these European and international party associations had close links to the three Europarties under consideration here, and those parties in CEE countries that established a formal affiliation with these organisations were credible potential members of the EPP, PES or ELDR, and were also highly likely to be in regular contact with these Europarties. ${ }^{11}$ Second, some parties

\footnotetext{
${ }^{10}$ The status of the party at the end of the election year is used for party-election dyads (i.e. in the analysis of electoral coalitions). For party-electoral period dyads (i.e. in the analysis of mergers), the status of parties in the first year after the election year is used. Steuwer (2006) was the main source on the parties in CEE countries with Europarties and international party organisations.

${ }^{11}$ The close links between the EPP, PES and ELDR and these other organisations are demonstrated by the fact that most Western European member parties of the three Europarties have also been formally affiliated to these other European and international party associations. In addition, all three Europarties have also had a formal linkage with the three party internationals. The links between the EUCD and EPP were even closer, as the EUCD was a de facto sattelite organisation of the EPP which was deliberately used in the 1990s by the latter to screen potential members in post-communist Europe (Öhlén, 2013). The EDU is somewhat of an exception, as it was an association of conservative and Christian democratic parties, which was formally independent from both the EPP or CDI. However, the substantial overlap of the membership in the EDU and EPP (as demonstrated, for example, by the participation of the German CDU in both organisations) and the joint group in the European Parliament assured a close collaboration between the
} 
were also coded as potential member parties with links to the Europarties if the documents of European or international party federations, media reports or academic sources indicate that (1) the Europarty attempted to convince these parties to form coalitions or merge with other parties in the same country, or (2) the Europarty considered these parties as potential members. $^{12}$

[Figure 2]

Potential member parties without ties to the Europarties were identified on the basis of their affiliation with one of eleven ideological party families. ${ }^{13}$ Specifically, all parties of the ideological family of the Europarty (Christian democracy and conservatism for the EPP, liberalism for the ELDR, and social democracy for the PES) that were not its members or potential parties with ties to it were coded as potential members without ties if there was no information available (in the archives of the Europarties, academic literature, and media reports) that the Europarty considered them as not acceptable due to their ideology (as indicated, for example, by the rejection of their membership applications) or affiliation with another European or international party federation.

The four categories of the variable Europarty influence were constructed as follows. Cooperation indicates the dyads where (1) the two parties were members of the same Europarty, or (2) one party was a member of the Europarty and the other one was its potential member

two organisations, which culminated in their merger in 2002 (Jansen and Van Hecke, 2011).

${ }^{12}$ The documents from the following archives were used to code this variable: the Archive of Christian Democracy in Sankt Augustin, Germany, the Archive of Liberalism in Gummersbach, Germany, and the EPP archive in Brussels, Belgium. Also, different issues of the Socialist Affairs (the official publication of the SI) were consulted. Europarty documents provide quite clear indications about the parties that were considered as potential members. For example, in the 1990s the ELDR developed and regularly updated the list of all potential member parties in CEE countries, which also ranked these parties in terms of their suitability as potential members. Also, in several cases internal Europarty documents indicated that applications from parties in CEE were received and, while still being processed, had high chances of being accepted.

${ }^{13}$ Party families were coded based on the coding scheme provided by Doring and Manow (2012). For the parties not included in that database various other sources were used, especially the handbooks on political parties, in particular Bugajski (2002). Alternative measures of party policy, such as Comparative Manifesto Project estimates or expert surveys, do not cover most of the small parties considered in this study. For this reason, some studies on government coalitions in Central and Eastern Europe also used party family variables for capturing ideological compatibility of governments (Grotz and Weber, 2012), although exceptions are also notable (Savage, 2014). 
(with or without a link with the Europarty), or (3) both parties were potential members of the same Europarty, but at least one of them had a link with it. This operationalisation is in line with Hypotheses 1 and 3, which suggested that member and potential member parties are more likely to cooperate if at least one of them has a link with a Europarty.

No cooperation indicates the dyads where (1) one party was a member of the Europarty or its potential member with a link to it, and (2) the other party was a radical left or right party. Such dyads should be less likely to lead to mergers and electoral coalitions, as suggested by Hypotheses 2 and 4 .

Ambivalence category captures these dyads in which one party was a member of the Europarty or its potential member with a link to it. The other party in these dyads was not a potential member of the Europarty but was not a radical right or communist party either. ${ }^{14}$ Finally, no link indicates the dyads where the two parties were neither members nor potential members with links to any of the three key Europarties.

The analysis also includes a number of control variables that capture the domestic costs and benefits of electoral coalitions and mergers. The counterfactual in Hypotheses 1 and 2 is that, had two parties were not (potential) members of the same Europarty with at least one of them having a link to this Europarty, cooperation between them would be less likely. Similarly, the counterfactual in Hypotheses 3 and 4 is that, for the dyads in which one party is a radical left or right party and the other party is a moderate party, the likelihood that they would have cooperated would have been higher if the moderate party was not a (potential) member of a Europarty with a link to it. The inclusion of control variables in the statistical analysis makes the party dyads in the sample more comparable, thus helping us to establish the causal effect (or the absence thereof) of Europarties on party coalitions and mergers.

While the explanations of the two phenomena may be somewhat different, for parsimony

\footnotetext{
${ }^{14}$ Some but not all of these parties were (potential) members of other Europarties. As mentioned above, Europarties may either oppose or support coalitions and mergers between such parties depending on the specific context.
} 
reasons the selection of control variables is largely based on the analysis of electoral coalitions in Central and Eastern Europe (Ibenskas, 2016b). Potential electoral and office benefits of electoral coalitions are captured by two dichotomous variables. The first variable takes a value of 1 if both parties in the dyad have the share of the vote lower than the size of the legal threshold plus two percentage points, thus indicating two small parties that individually may not be able to gain legislative representation. ${ }^{15}$ The second variable takes a value of 1 if only one of the parties in the dyad is small, meaning that its share of the vote is below the legal threshold plus two percentage points. Electoral cooperation in this case could provide legislative representation to the smaller partner and an important coalition partner to the larger partner. Potential electoral benefits of mergers are captured by the square root of the absolute difference between the expected vote share of merged party and the legal electoral threshold. Similarly, following Ibenskas (2016a), the square root of the absolute difference between the expected vote share of the merged party and the 30 percent threshold captures potential office benefits. Lower values of each of these two measures therefore indicate that the expected support of the merged party is closer to the threshold, thus creating higher incentives for parties to merge. The square root transformation embeds the assumption that the changes in the distance between the expected vote share and the threshold is more important for lower values of distance. On the contrary, if parties' expected support is, for example, substantially above the legal electoral threshold, limited changes in support should only marginally affect parties' incentives to cooperate.

Ideological similarity is indicated by the affiliation of both parties with the same party family (Christian democratic and conservative parties are also coded as being part of the same family). The analysis also includes the dichotomous variable for open-list systems, which make inter-party deals on the distribution of legislative seat candidacies less credible. Previous cooperation in electoral coalitions also decreases the distributional costs of both

\footnotetext{
${ }^{15}$ Legal thresholds, which with the exception of Croatia are nationwide, can be considered as the main institutional threshold to the representation of small parties in Central and Eastern Europe, at least since the second democratic election in these countries (Bochsler, 2010).
} 
coalitions and mergers. The presence of the genuinely new party in the dyad should decrease the probability of a coalition or merger, as these new parties would lose part of their valence appeal by collaborating with established parties in the system. The analysis also controls for the dyads that include one extreme left or right party and a moderate party. Yet another control variable indicates the dyads that include a communist successor party. The control variable for communist successor parties is interacted with the age of democracy, as the attractiveness of these formerly authoritarian parties as coalition or merger partners clearly changed since the early democratic period in post-communist countries.

\section{Analyses}

Table 3 presents four specifications of the statistical models of electoral coalitions and party mergers. Control variables are included in Models 2 and 4, but not in Models 1 and 3. No link is used as a reference category of the Europarty influence variable. Random-effects logit models with clustering of intercepts at the level of elections (Models 1-2) or electoral periods (Models 3-4) are used in order to account for factors idiosyncratic to individual elections or electoral periods. ${ }^{16}$ Figures 3 and 4 summarise the substantive effects of all predictor variables.

\section{[Table 3] [Figures 3 and 4]}

\section{Electoral coalitions}

The analysis of electoral coalitions shows that member and/or potential member parties with links to Europarties are not more likely to cooperate among themselves, thus rejecting Hypothesis 1. Although the cooperation category has a positive and statistically significant coefficient in Model 1, it loses both substantive and statistical significance in a more fully specified Model 2.

\footnotetext{
${ }^{16}$ The results reported below hold also in rare-event logistic regression models reported in the Online Appendix.
} 
In contrast, no cooperation is statistically significant in Model 1 and remains such in Model 2 (although the substantive effect is weaker). Thus, Europarties are able to reduce the probability of electoral coalitions between (1) their members or potential members and (2) radical left or right parties. According to the estimates of Model 2, such coalitions are, all else equal, 68 percent (95\% CI: 88 and 20) less likely to occur than the coalitions between the parties without links to the Europarties. This effect persists even when we include in the statistical model a variable that indicates dyads that include one extreme left or right party and a moderate party. This latter variable is also statistically significant, suggesting that moderate parties are generally less likely to cooperate with extreme parties, but also that members or potential members of Europarties are even less likely to do so in comparison to other moderate parties. This is key in light of our theoretical argument.

These findings suggest that the threat to Europarties' interests, values and identity posed by a potential cooperation of their national member parties or potential member parties with radical left and right parties is of greater importance to them than the potential gains of the electoral cooperation among their member and potential member parties. The electoral collaboration with radical parties that do not fully commit to liberal democratic values is an anathema for the officials of the three mainstream Europarties and their most important national parties in core EU member states. Central and Eastern European parties that openly engage in such "undesirable" cooperation thus challenge the fundamental values (and possibly the reputation) of the Europarties that they are associated with. This motivates the latter's strong efforts to prevent such coalitions on behalf of the former. For example, in 1997 the European Union of Christian Democrats (an EPP-affiliate that represented it in relations with parties in CEE) excluded the Hungarian Christian Democratic Party (KDNP) after its leadership participated in the rallies organised by the radical right Hungarian Life and Justice Party (MIEP). The EPP was also quite successful in preventing the cooperation between the Croatian Democratic Union (HDZ), a strongly nationalist party in the 1990s, and radical right parties in Croatia in the 2000s and 2010s. Only following the election of the 
rightist leader Tomislav Karamarko in 2012 the HDZ formed an electoral coalition with the radical right Croatian Party of Rights - Ante Starcevic (HSP-AS) as part of a broad rightist coalition. The EPP criticised the HDZ for this decision prior to the 2014 European election (Mikucka-Wójtowicz, 2016, 249). However, the HDZ swiftly terminated its coalition with the HSP-AS prior to the 2016 general election, following the election of Andrej Plenkovic, an MEP and a former diplomat with long experience of working on Croatia's European integration. The election of Plenkovic as the new leader of HDZ was strongly supported by the EPP and its European Parliament group, and Plenkovic emphasised the membership of the HDZ in the EPP during the 2016 general election campaign.

In contrast, the electoral competition between the member parties of the same Europarty is relatively common in some Western European countries (e.g. France or Italy), thus making it more acceptable in Central and Eastern European countries as well. Moreover, parties in electoral coalitions remain independent (potential) members of the Europarty, thus doing little to reduce its organisational complexity. The Europarties are therefore likely to support electoral coalitions among their (potential) member parties only if such coalitions seem necessary for the electoral survival of these parties and/or full-blown organisational mergers at the later stage. When the member parties are unlikely to merge and are relatively secure electorally, the Europarty is likely to emphasise cooperation in post-electoral coalitions instead. For example, in 2003-2007 the EPP criticised the Croatian People's Party (HSS) its observer party at the time - for opposing the government led by the HDZ. The role of the EPP also seemed important in encouraging the governmental coalition between the HDZ and HSS after the 2007 general election (Mikucka-Wójtowicz, 2016, 249). However, there is little evidence that the EPP would have pushed HSS and HDZ to cooperate in elections as well due to the substantial policy differences between these parties.

Moreover, the coefficient of the Ambivalence category is statistically significant in Model 2 (but not in Model 1). However, the substantive effect of this variable is relatively weak, especially in comparison to the No cooperation category. The dyads that include member 
or potential member parties on the one hand and moderate parties that represent other party families on the other hand are, all else equal, 29 percent (95\% CI: 47 and 4) less likely to occur than the coalitions between the parties without links to the Europarties. This finding suggests that Europarties may discount electoral benefits that such coalitions can provide to their (potential) member parties or the positive implications of such coalitions for democratic consolidation. Instead, the risk that such coalitions would lead their (potential) member parties to adopt positions that are incompatible with the ideological principles of the Europarty seems to be more important.

\section{Mergers}

Turning to the analysis of party mergers, our results support Hypothesis 3, but not Hypothesis 4. According to the estimates of Model 4, the mergers between member and potential member parties of the same Europarty are, all else equal, 221 percent (95\% CI: 63 and 549) more likely to occur than the mergers between the parties without links to the Europarties. The ability of the Europarties to prevent the mergers of their (potential) members with radical left and right parties, although present in Model 3, disappears in the more fully-specified Model 4. The effect of the Europarties on the mergers between their (potential) member parties and other moderate parties is also not significant, both substantively and statistically.

These findings further support the argument that mergers are encouraged by Europarties more than electoral coalitions. Such mergers often occur without prior electoral coalitions. For example, the PES played an important role in bringing about the mergers among the centre-left parties in Bulgaria, Romania and Slovakia (Pridham, 2014). In Lithuania, the socialisation in European and transnational party organisations contributed to the merger between two liberal parties (the Liberal Union and the Centre Union) in 2003. ${ }^{17}$

The null finding of the effect of Europarties on mergers of their member or potential

\footnotetext{
${ }^{17}$ Interviews with the leadership of the Liberal Centre Union, 4th of November, 2014.
} 
member parties and radical parties may have occurred because mergers between moderate and radical left and right parties are highly unlikely for other reasons. Model 4 demonstrates a substantively strong negative effect of the variable indicating dyads of moderate and radical parties on the probability of party mergers (although this effect is not statistically significant). More generally, mergers between parties that represent different ideological party families are much less likely than those between the parties that belong to the same family. Furthermore, Model 4 also shows a very strong effect of the prior electoral coalition on the probability of party merger. This latter finding is important because, as Model 2 indicates, electoral coalitions between moderate parties and radical left or right parties are unlikely. Thus, although Europarties are highly likely to object to the mergers of their member parties with extreme parties, their intervention is not required since the benefits of such cooperation for the former parties seem too low in the first place.

\section{Control variables}

While Europarty influence on electoral coalitions and mergers among the CEE parties is important, domestic explanations identified in previous research have substantively stronger effects. Figure 3 shows that the effects of electoral institutions and party size, history, ideology and experience of previous cooperation on electoral coalitions are comparable or stronger to the impact of Europarties. Figure 4 reports similar results with regard to mergers. Nevertheless, the finding that Europarties are able to influence some of the most important strategic decisions of parties in CEE countries underscores their importance for these parties and also calls for more research on other areas (e.g. programmatic or organisational decisions of CEE parties) in which Europarties can exert their influence. 


\section{Conclusion}

The present study tested the argument that the key Europarties play a role in promoting the coalitions and mergers among their member or potential member parties in Central and Eastern Europe, and to prevent the cooperation of these parties with other parties in the system. We argued that Europarties affect party cooperation through two channels: (1) by making the provision of various benefits (especially full membership in the Europarty) to CEE parties conditional on cooperating among themselves in national politics, and (2) by using the socialisation and persuasion of these parties' elites or future elites. We find moderate support to this argument by conducting rigorous statistical analyses that control for a substantial number of other factors that may affect party cooperation. Specifically, Europarties facilitate mergers (but not electoral coalitions) of their member or potential member parties and prevent electoral coalitions between their member and potential member parties and radical left and right parties. We find no effect of Europarties on electoral coalitions and mergers between their (potential) member parties and other moderate parties that represent different ideological party families.

These findings indicate a stronger degree of structural or organisational institutionalisation in the key Europarties, at least with respect to their relations with parties in Central and Eastern Europe. In a way reminiscent of the relationship between national parties and their regional or local chapters, Europarties exert some influence on the identity and cooperation strategy of their national member parties. Moreover, the present research also contributes to the debate on the Europeanisation of party politics in Central and Eastern Europe by showing that, in contrast to some accounts in this literature, Europarties affect the development of party systems in these countries through mergers and electoral coalitions. Their role does encompass defending very broad "boundaries of the permissible and acceptable" (Haughton, $2014,83)$, that is, seeking to prevent any major democratic deficiencies. Additionally, the Europarties continue to shape party system development through the promotion of merg-

ers between ideologically similar parties in an attempt to consolidate their ideological and 
electoral presence on the national political scene.

Biographical statement: Raimondas Ibenskas is Lecturer at the Department of Politics and International Relations, School of Social Sciences, University of Southampton. His research interests are party politics and European Union politics. His work has been published in the British Journal of Political Science, Journal of Politics, Public Administration, European Journal of Political Research, European Union Politics, and Party Politics. 


\section{References}

Bakke, Elisabeth. 2010. Central and East European Party Systems. In Central and Southeast European Politics since 1989, ed. Sabrina P. Ramet. Cambridge: Cambridge University Press pp. 64-91.

Blais, André and Indridi H. Indridason. 2007. "Making candidates count: the logic of electoral alliances in two-round legislative elections." Journal of Politics 69(1):193-205.

Bochsler, Daniel. 2010. Territory and electoral rules in post-communist democracies. Houndmills: Palgrave Macmillan.

Bressanelli, Edoardo. 2014. Europarties After Enlargement: Organization, Ideology and Competition. Basingstoke: Palgrave.

Bugajski, Janusz. 2002. Political parties of Eastern Europe: a guide to politics in the postCommunist era. New York: ME Sharpe Inc.

Carothers, Thomas. 2006. Confronting the Weakest Link. Washington: Carnegie Endowment.

Checkel, Jeffrey T. 2005. "International institutions and socialization in Europe: Introduction and framework." International Organization 59(4):801-826.

Dakowska, Dorota. 2002. "Beyond conditionality: EU enlargement, European party federations and the transnational activity of German political foundations." Perspectives on European Politics and Society 3(2):271-296.

Delsoldato, Giorgia. 2002. "Eastward enlargement by the European Union and transnational parties." International Political Science Review 23(3):269-289.

Doring, Holger and Philip Manow. 2012. "Parliament and government composition database (ParlGov).".

Ferrara, Federico and Erik S. Herron. 2005. "Going it alone? Strategic entry under mixed electoral rules." American Journal of Political Science 49(1):16-31.

Gerring, John. 2011. Social science methodology: A unified framework. Cambridge: Cambridge University Press.

Golder, Sona N. 2005. "Pre-electoral coalitions in comparative perspective: A test of existing hypotheses." Electoral Studies 24(4):643-663.

Golder, Sona N. 2006. The logic of pre-electoral coalition formation. Columbus: Ohio State University Press.

Grotz, Florian and Till Weber. 2012. "Party systems and government stability in Central and Eastern Europe." World Politics 64(4):699-740. 
Gschwend, Thomas and Marc Hooghe. 2008. "Should I stay or should I go? An experimental study on voter responses to pre-electoral coalitions." European Journal of Political Research 47(5):556-577.

Hall, Peter A. and Rosemary C. R. Taylor. 1996. "Political science and the three new institutionalisms*." Political studies 44(5):936-957.

Harmel, Robert and Kenneth Janda. 1994. "An integrated theory of party goals and party change." Journal of Theoretical Politics 6(3):259.

Haughton, Tim. 2009. "Driver, conductor or fellow passenger? EU membership and party politics in Central and Eastern Europe." Journal of Communist Studies and Transition Politics 25(4):413-426.

Haughton, Tim. 2014. "Money, Margins and the Motors of Politics: The EU and the Development of Party Politics in Central and Eastern Europe." Journal of Common Market Studies 52(1):71-87.

Holmes, Michael and Simon Lightfoot. 2011. "Limited influence? The role of the Party of European Socialists in shaping social democracy in Central and Eastern Europe." Government and Opposition 46(1):32-55.

Ibenskas, Raimondas. 2016a. "Marriages of Love or Convenience: Party Mergers in Established and New European Democracies." Journal of Politics 78(2):343-356.

Ibenskas, Raimondas. 2016b. "Understanding Pre-Electoral Coalitions in Central and Eastern Europe." British Journal of Political Science 46(4):743-761.

Ibenskas, Raimondas and Allan Sikk. 2017. "Patterns of party change in Central and Eastern Europe, 1990-2015." Party Politics 23:43-54.

Jansen, Thomas and Steven Van Hecke. 2011. At Europe's Service: The Origins and Evolution of the European People's Party. Heidelberg: Springer.

Kaminski, Marek M. 2001. "Coalitional stability of multi-party systems: Evidence from Poland." American Journal of Political Science 45(2):294-312.

Kubicek, Paul J. 2003. The European Union and Democratization. London: Routledge.

Levitsky, Steven and Lucan A Way. 2006. "Linkage versus leverage. Rethinking the international dimension of regime change." Comparative Politics 38:379-400.

Lipset, Seymour M. and Stein Rokkan. 1967. Party systems and voter alignments: crossnational perspectives. New York: Free Press.

Mikucka-Wójtowicz, Dominika. 2016. "Resilient or resistant? The impact of transnational party cooperation on Croatian political parties." East European Politics 32(2):236-257.

Öhlén, Mats. 2013. The eastward enlargement of European parties: Party adaptation in the light of EU-enlargement. Orebro: Orebro Studies in Political Science. 
Pridham, Geoffrey. 2006. Patterns of Europeanization and Transnational Party Cooperation: Party Development in Central and Eastern Europe. In Party Development and Democratic Change in Post-Communist Europe: The First Decade, ed. Paul G. Lewis. London: Frank Cass p. 179198.

Pridham, Geoffrey. 2014. "Comparative perspectives on transnational party-building in new democracies: The case of Central and Eastern Europe." Acta Politica 49(1):30-50.

Randall, Vicky and Lars Svasand. 2002. "Party institutionalization in new democracies." Party Politics 8(1):5.

Savage, Lee Michael. 2014. "Who gets in? Ideology and government membership in Central and Eastern Europe." Party Politics 20(4):547-562.

Schimmelfennig, Frank and Hanno Scholtz. 2008. "EU Democracy promotion in the European neighbourhood: political conditionality, economic development and transnational exchange." European Union Politics 9(2):187-215.

Schimmelfennig, Frank and Ulrich Sedelmeier. 2005. Introduction: Conceptualizing the Europeanization of Central and Eastern Europe. In The Europeanization of Central and Eastern Europe, ed. Frank Schimmelfennig and Ulrich Sedelmeier. Ithaca: Cornell University Press pp. 1-28.

Sedelmier, Ulrich. 2011. "Europeanisation in new member and candidate states." Living Reviews in European Governance 6(1).

Spirova, Maria. 2007. Political parties in post-communist societies: formation, persistence, and change. New York: Palgrave Macmillan.

Spirova, Maria. 2008. "Europarties and party development in EU-candidate states: The case of Bulgaria." Europe-Asia Studies 60(5):791-808.

Steuwer, Janosch. 2006. Dokumentation. In Politische Parteien und europäische Integration. Entwicklung und Per- spektiven transnationaler Pateienkoorperation in Europa, ed. Jürgen Mittag. Essen: Klartext Verlag pp. 725-746.

Timuş, Natalia. 2014. "Transnational party Europeanization: EPP and Ukrainian parties." Acta Politica 49(1):51-70.

Vachudova, Milada Anna. 2005. Europe undivided: democracy, leverage, and integration after communism. Oxford: Oxford University Press.

von dem Berge, Benjamin and Thomas Poguntke. 2013. "The influence of Europarties on Central and Eastern European partner parties: a theoretical and analytical model." European Political Science Review 5(02):311-334.

Zielinski, Jakub. 2002. "Translating Social Cleavages into Party Systems: The Significance of New Democracies." World Politics 54(1):184-211. 
Table 1: Effects of electoral coalitions and mergers of CEE national parties on Europarties

\begin{tabular}{|c|c|c|c|c|c|c|c|}
\hline $\begin{array}{l}\text { National } \\
\text { party A }\end{array}$ & $\begin{array}{l}\text { National } \\
\text { party B }\end{array}$ & $\begin{array}{l}\text { Type of } \\
\text { cooperation }\end{array}$ & $\begin{array}{l}\text { AB affiliated } \\
\text { with Europarty? }\end{array}$ & $\begin{array}{l}\text { Europarty's } \\
\text { org. instit. }\end{array}$ & $\begin{array}{l}\text { Europarty's } \\
\text { value instit. }\end{array}$ & $\begin{array}{l}\text { Europarty's } \\
\text { influence }\end{array}$ & $\begin{array}{l}\text { Impl. for } \\
\text { democracy }\end{array}$ \\
\hline \multirow{2}{*}{$\begin{array}{l}\text { (Potential) } \\
\text { member } \\
\text { party }\end{array}$} & \multirow{2}{*}{$\begin{array}{l}\text { (Potential) } \\
\text { member } \\
\text { party } \\
\text { party }\end{array}$} & Merger & Yes & Higher & - & Higher & $\begin{array}{l}\text { Potentially } \\
\text { positive }\end{array}$ \\
\hline & & El. coalition & Yes/no & - & - & Higher & $\begin{array}{l}\text { Potentially } \\
\text { positive }\end{array}$ \\
\hline \multirow{3}{*}{$\begin{array}{l}\text { (Potential) } \\
\text { member } \\
\text { party }\end{array}$} & \multirow{3}{*}{$\begin{array}{l}\text { Not a } \\
\text { (potential) } \\
\text { member } \\
\text { party, } \\
\text { radical } \\
\text { ideology }\end{array}$} & Merger & Yes & - & Lower & $\begin{array}{l}\text { Potentially } \\
\text { lower }\end{array}$ & Negative \\
\hline & & Merger & No & - & - & Lower & Negative \\
\hline & & El. coalition & Yes/no & - & Lower & $\begin{array}{l}\text { Potentially } \\
\text { lower }\end{array}$ & Negative \\
\hline \multirow{3}{*}{$\begin{array}{l}\text { (Potential) } \\
\text { member } \\
\text { party }\end{array}$} & \multirow{3}{*}{$\begin{array}{l}\text { Not a } \\
\text { (potential) } \\
\text { member } \\
\text { party, } \\
\text { moderate } \\
\text { ideology }\end{array}$} & Merger & Yes & - & Lower & Higher & $\begin{array}{l}\text { Potentially } \\
\text { positive }\end{array}$ \\
\hline & & Merger & No & - & - & Lower & $\begin{array}{l}\text { Potentially } \\
\text { positive }\end{array}$ \\
\hline & & El. coalition & Yes/no & - & Lower & Higher & $\begin{array}{l}\text { Potentially } \\
\text { positive }\end{array}$ \\
\hline
\end{tabular}

Table 2: Operationalisation of the relationship between the Europarties and national parties in $\mathrm{CEE}$

\begin{tabular}{|c|c|c|c|}
\hline Party category & EPP & PES & ELDR \\
\hline Full member party & Full member of EPP & Full member of PES & Full member of ELDR \\
\hline $\begin{array}{l}\text { Associate/ affiliate / observer } \\
\text { member party }\end{array}$ & $\begin{array}{l}\text { Observer or associate } \\
\text { member of EPP }\end{array}$ & $\begin{array}{l}\text { Observer or associate } \\
\text { member of PES }\end{array}$ & $\begin{array}{l}\text { Observer or affiliate } \\
\text { member of ELDR }\end{array}$ \\
\hline $\begin{array}{l}\text { Potential member } \\
\text { party with a tie } \\
\text { to the Europarty }\end{array}$ & $\begin{array}{l}\text { Formal affiliation with } \\
\text { EUCD, CDI, and EDU, OR } \\
\text { evidence that the party }\end{array}$ & $\begin{array}{l}\text { Formal affiliation } \\
\text { with SI, OR } \\
\text { as considered as a potential member }\end{array}$ & $\begin{array}{l}\text { Formal affiliation } \\
\text { with LI, OR } \\
\text { r by the Europarty }\end{array}$ \\
\hline $\begin{array}{l}\text { Potential member party } \\
\text { without a tie to the Europarty }\end{array}$ & $\begin{array}{r}\text { ChrDem or Con party, AND } \\
\text { no evidence } \\
\text { on th }\end{array}$ & $\begin{array}{l}\text { SocDem or Socialist party, AND } \\
\text { the ties to the Europarty, AND no e } \\
\text { arty being ideologically unacceptabl }\end{array}$ & $\begin{array}{l}\text { Liberal party, AND } \\
\text { evidence } \\
\text { le }\end{array}$ \\
\hline
\end{tabular}


Table 3: Random-effects logit models of electoral coalitions and mergers

\begin{tabular}{|c|c|c|c|c|}
\hline & \multicolumn{2}{|c|}{ Electoral coalitions } & \multicolumn{2}{|c|}{ Mergers } \\
\hline & Model 1 & Model 2 & Model 3 & Model 4 \\
\hline Intercept & $\begin{array}{c}-3.12^{* * *} \\
(0.19)\end{array}$ & $\begin{array}{c}-3.34^{* * *} \\
(0.49)\end{array}$ & $\begin{array}{c}-4.75^{* * *} \\
(0.30)\end{array}$ & $\begin{array}{c}0.31 \\
(1.62)\end{array}$ \\
\hline \multicolumn{5}{|c|}{ Europarty influence (reference category - no link) } \\
\hline Cooperation & $\begin{array}{c}0.91^{* * *} \\
(0.17)\end{array}$ & $\begin{array}{l}-0.21 \\
(0.22)\end{array}$ & $\begin{array}{c}1.97^{* * *} \\
(0.26)\end{array}$ & $\begin{array}{l}1.14^{* *} \\
(0.35)\end{array}$ \\
\hline Ambivalent & $\begin{array}{l}-0.08 \\
(0.13)\end{array}$ & $\begin{array}{c}-0.33^{*} \\
(0.16)\end{array}$ & $\begin{array}{c}0.31 \\
(0.23)\end{array}$ & $\begin{array}{c}0.25 \\
(0.30)\end{array}$ \\
\hline No cooperation & $\begin{array}{c}-2.22^{* * *} \\
(0.45)\end{array}$ & $\begin{array}{c}-1.17^{*} \\
(0.49)\end{array}$ & $\begin{array}{c}-1.47^{*} \\
(0.74)\end{array}$ & $\begin{array}{c}0.47 \\
(0.95)\end{array}$ \\
\hline \multicolumn{5}{|l|}{ Control variables } \\
\hline Two small parties & & $\begin{array}{c}1.47^{* * *} \\
(0.35)\end{array}$ & & \\
\hline Small+larger party & & $\begin{array}{l}0.67^{*} \\
(0.34)\end{array}$ & & \\
\hline Close to legal threshold & & & & $\begin{array}{c}-0.71^{* * *} \\
(0.21)\end{array}$ \\
\hline Close to 30 percent & & & & $\begin{array}{c}-1.00^{* * *} \\
(0.26)\end{array}$ \\
\hline Ideological similarity & & $\begin{array}{c}1.09^{* * *} \\
(0.17)\end{array}$ & & $\begin{array}{c}0.95^{* *} \\
(0.30)\end{array}$ \\
\hline Genuinely new party & & $\begin{array}{c}-0.68^{* * *} \\
(0.19)\end{array}$ & & $\begin{array}{c}-0.81^{*} \\
(0.40)\end{array}$ \\
\hline Non-closed list & & $\begin{array}{c}-0.91^{* *} \\
(0.29)\end{array}$ & & $\begin{array}{c}0.70 \\
(0.58)\end{array}$ \\
\hline Previous electoral coalition & & $\begin{array}{c}2.54^{* * *} \\
(0.20)\end{array}$ & & $\begin{array}{c}3.30^{* * *} \\
(0.28)\end{array}$ \\
\hline Com. successor & & $\begin{array}{c}0.26 \\
(0.22)\end{array}$ & & $\begin{array}{c}-1.09^{*} \\
(0.53)\end{array}$ \\
\hline Age of democracy & & $\begin{array}{l}-0.02 \\
(0.02)\end{array}$ & & $\begin{array}{l}-0.09 \\
(0.05)\end{array}$ \\
\hline Radical party & & $\begin{array}{c}-1.25^{* * *} \\
(0.28)\end{array}$ & & $\begin{array}{l}-0.93 \\
(0.70)\end{array}$ \\
\hline Election-level variance & 1.19 & 0.72 & 1.39 & 1.73 \\
\hline Log Likelihood & -1112.75 & -931.78 & -453.05 & -332.18 \\
\hline $\mathrm{N}$ & 4565 & 4565 & 4093 & 4093 \\
\hline Number of elections / electoral periods & 64 & 64 & 53 & 53 \\
\hline
\end{tabular}

${ }^{* * *} p<0.001,{ }^{* *} p<0.01,{ }^{*} p<0.05$. 
Figure 1: Number of electoral coalitions and mergers per country

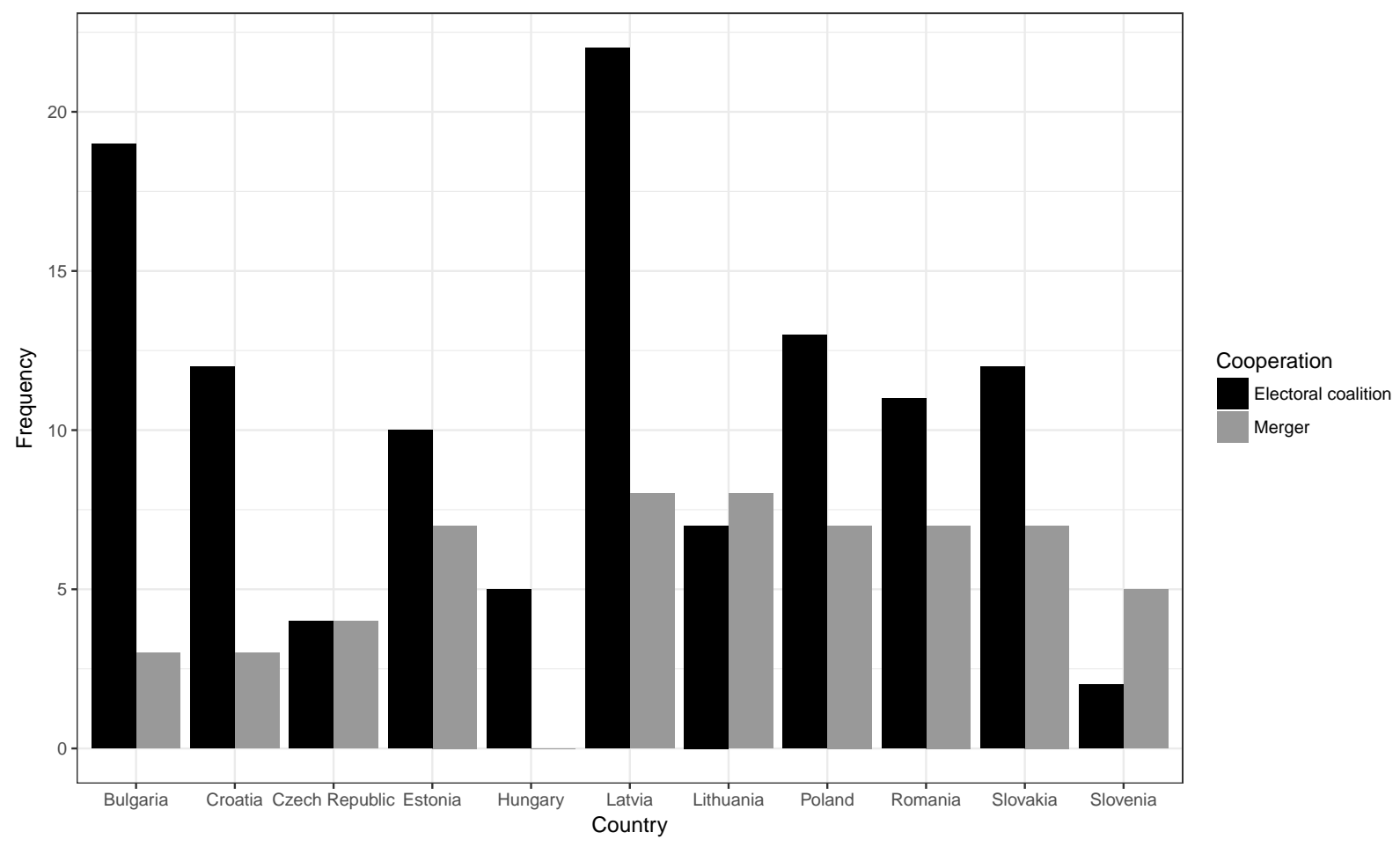


Figure 2: Ties between the Europarties and parties in Central and Eastern Europe

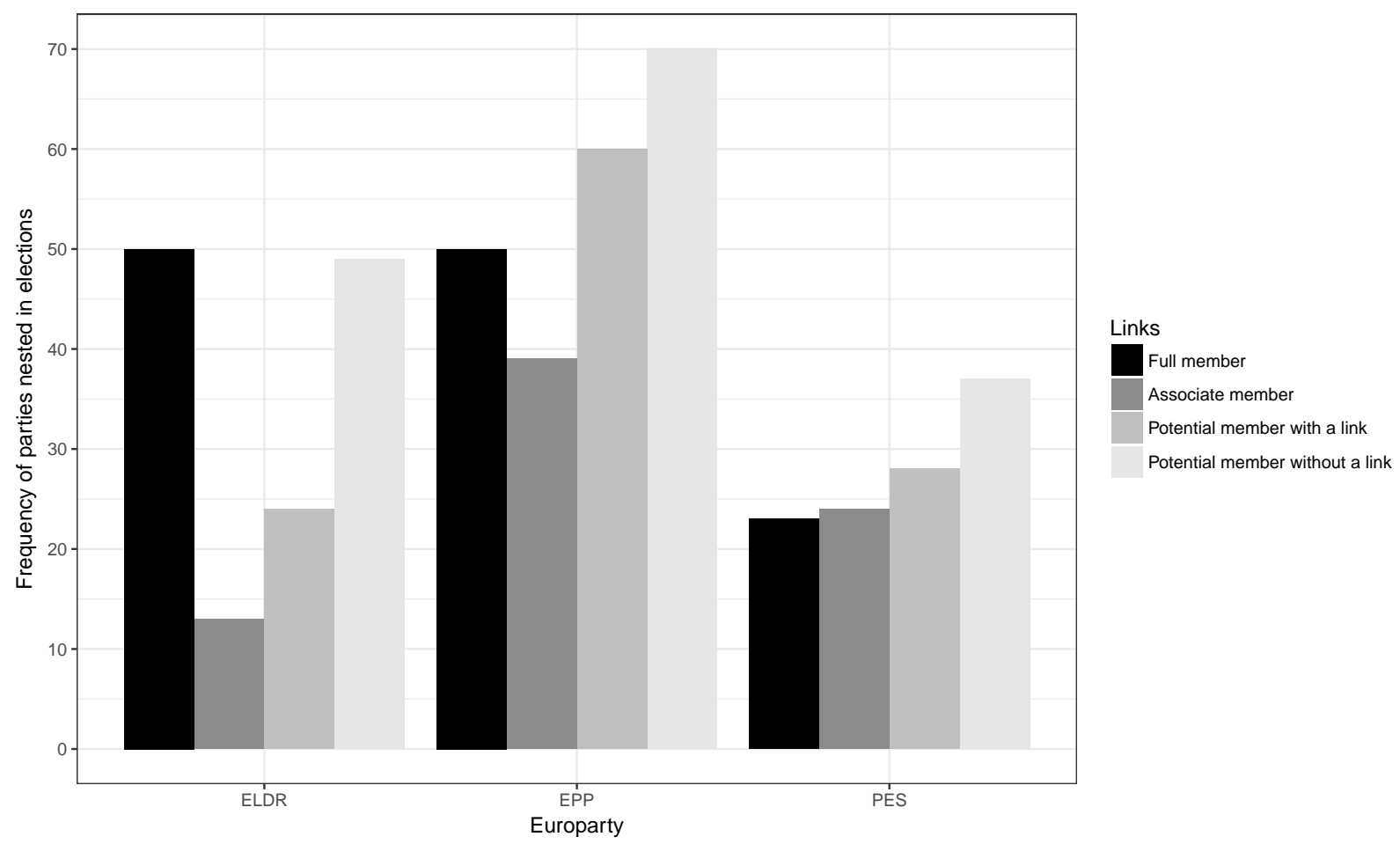


Figure 3: Effect of predictor variables on electoral coalitions

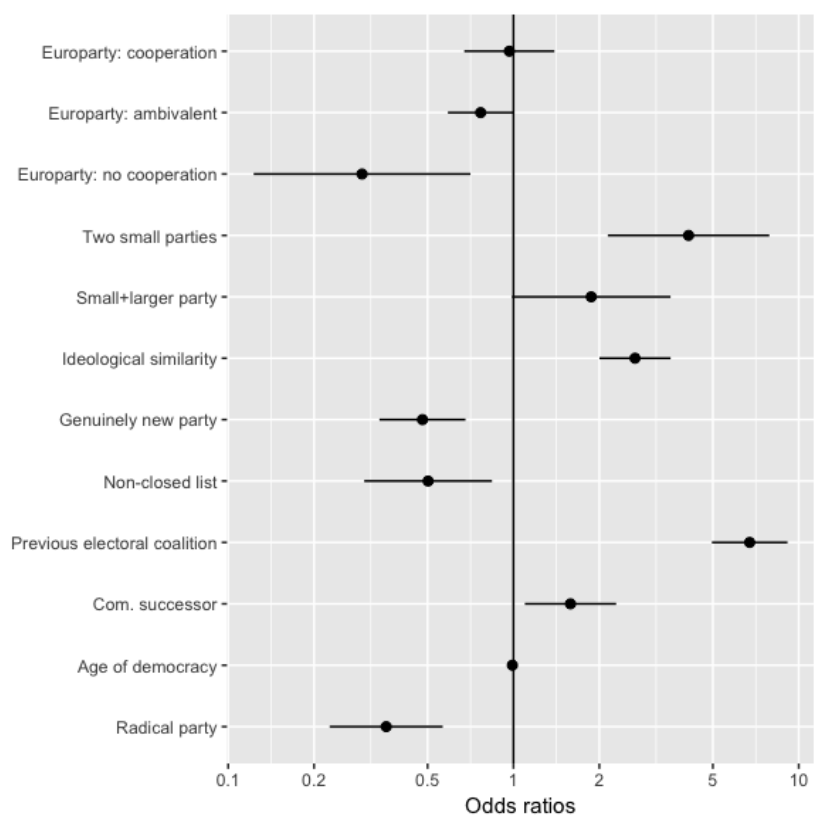


Figure 4: Effect of predictor variables on mergers

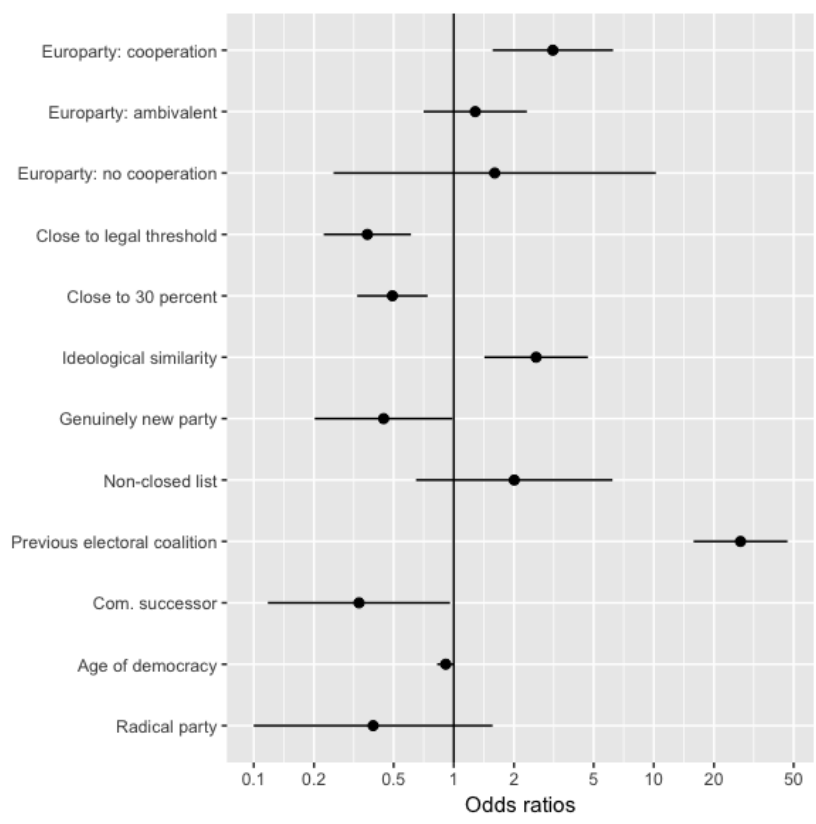

